\title{
Neutrophil Actin Defect
}

National Cancer Institute

\section{Source}

National Cancer Institute. Neutrophil Actin Defect. NCI Thesaurus. Code C61243.

A genetic disorder characterized by defective polymorphonuclear cell actin function, resulting in impaired granulocyte motility. 